\title{
DEVELOPING CULTURE-BASED ENGLISH INSTRUCTIONAL MATERIALS TO IMPROVE STUDENTS' THINKING, ELT ACHIEVEMENT, AND CLASSROOM INTERACTION
}

\author{
Zukhairatunniswah Prayatii; Haerazi²*; Lalu Ari Irawan³; Rully May Vikasari ${ }^{4}$ \\ ${ }^{1-4}$ English Language Education, Faculty of Culture, Management, and Business, Mandalika University of Education \\ Jl. Pemuda No. 59 A Mataram, Nusa Tenggara Barat 83125, Indonesia \\ 1'anisprayati@gmail.com; ${ }^{2}$ haerazi@ikipmataram.ac.id; ${ }^{3}$ laluariirawan@ikipmataram.ac.id; ${ }^{4}$ momvika@gmail.com
}

Received: $27^{\text {th }}$ August 2020/Revised: $23^{\text {rd }}$ September 2020/Accepted: $28^{\text {th }}$ September 2020

\begin{abstract}
How to Cite: Prayati, Z., Haerazi., Irawan, L. A., \& Vikasari, R. M. (2020). Developing culture-based English instructional materials to improve students' thinking, ELT achievement, and classroom interaction.

Lingua Cultura, 14(2), 211-218. https://doi.org/10.21512/lc.v14i2.6650
\end{abstract}

\begin{abstract}
The research aimed to provide students' learning and target needs of incorporating culture-based English instructional materials in enhancing students' critical thinking skills, ELT achievement, and classroom interaction at the Central Lombok middle schools. The research was a quantitative study. The 350 students and 10 English teachers were involved in the research. The average of students' age ranged from 12-13 years old, while the English teachers were certified English teachers at the middle schools. They had also been from five to seven years of teaching practice experience. The data were collected using a questionnaire to see the students' and teachers'needs that were focused on target needs and learning needs. The target needs comprised the learning goals, lacks, and wants, while the learning needs included learning inputs, students' roles, and classroom management. The data were analyzed using some steps; computation, display, drawing conclusion, and verification processes. Based on the data analysis, the target needs show that students are expected to get English proficiencies by providing them various cultural materials, namely local arts, traditional games, traditional rates, traditional technologies, and traditional pieces of literature. It can bring them to think critically to improve ELT achievement and build classroom interaction. At the same time, the analysis of learning needs informs that students need an appropriate English learning approach. They show they have an intention to be autonomous learners.
\end{abstract}

Keywords: culture-based materials, students' critical thinking, ELT teaching-learning, classroom interaction

\section{INTRODUCTION}

The need to insert cultures in instructional materials is essential nowadays because language and culture are inseparable (Haerazi et al., 2018). It is in line with Dinh and Sharifian (2017), who state that culture has attracted attention from English teachers as a result of the intertwined relation between culture and language. Some studies show that cultures are inserted in English Language Teaching (ELT) materials to improve intercultural or cultural communicative competencies and language proficiencies (Tamimy, 2019; Haerazi \& Irawan, 2020a). These studies have applied different strategies and methods, such as document analysis and classroom action based on diverse cultural references. The context of the current research is Indonesian, where English is employed as a foreign language. This research is oriented to investigate the incorporation of Indonesia's local cultures in the local ELT textbooks.

In inserting local or target culture onto English teaching materials, English teachers are necessary to conduct a need analysis of students' target and learning needs. It is aimed at knowing a piece of cultures they recognize and internalize to learn in the English as a Foreign Language (EFL) class. This consideration comes from the views of defining cultures in applied linguistics. According to Alaei and Parsazadeh (2020), English teachers need to delve into a number of main concepts and classification of cultures before they go to adapt or adopt cultures into teaching materials. In this context, teachers should pay attention to terms of world Englishes and Kachru's concentric model (Sridhar, 2019). Kachru's model in terms of English 
language consists of the inner-circle (countries in which English is used as a first language), outer circle (countries in which English is the official or second language), and expanding circle (the countries in which English is taught as a foreign language) (Kubota, 2018; Joo, Chik, \& Djonov, 2020). The inner-circle cultures seem to be appropriate to be inserted in textbooks for learners who learn English as a foreign language.

English teaching materials or textbooks should incorporate students' cultural background and provide them with various cultural comprehension and explanation as not to pawn misunderstanding (Shin, Eslami, \& Chen, 2011). The students' cultural background is then called local culture, and the inner circle cultures are classified as the target cultures. The problem of students is in which they are demanded to comprehend their own cultures before they go to the target cultures (Forman, 2014). To solve students' problems, the teaching materials should be designed in line with their needs (target needs and learning needs). The target needs refer to what the students need to learn, while learning needs refer to what students need to learn (Rachmawati, 2020; Haerazi et al., 2018). Before developing the teaching materials, teachers have to analyze the appropriate local cultures or target cultures to partake. Since textbooks or teaching materials are developed to strengthen character education as the main picture of the Indonesian curriculum (Setyono \& Widodo, 2019).

In the Indonesian context of EFL material development, English teaching is directed to improve students' critical thinking, communication, collaboration, and creativity. It is in accordance with $21^{\text {st }}$-century learning skills (Haerazi, Vikasari, $\&$ Prayati, 2019). In the research, the analysis is directed to teachers' efforts of incorporating culturebased materials to enhance students' critical thinking skills, achievement, and classroom interaction. A reflection of needs analysis of cultural depiction in terms of target needs and learning needs to develop culture-based English materials in Indonesian contexts, such as Central Lombok, is significant to be conducted, to extend empirical studies on a need analysis incorporation of culture-based instructional materials or textbooks. The research's contribution includes that research findings can be a catalyst for English materials developers to design and develop intercultural language learning materials to promote critical thinking skills, academic achievement, and autonomous learners (Kusumaningputri \& Widodo, 2018; Safitri \& Sugirin, 2019).

The culture-based English language learningteaching nowadays attracts English textbook developers as the curriculum expert views a conception that language and culture are intertwined (Baker, 2017). In this context, English language and cultural learning become the crucial issue in the EFL curriculum development (Su, 2016). English teachers from the countries in which English is taught as a foreign language encourage cultural instruction in EFL classes (Imig, 2016). The insertion of cultures in textbooks is not only in ELT practices but also in the other discipline (Niman et al., 2020). In the research, the researchers focus on the EFL context, specifically West Nusa Tenggara province Indonesia. The insertion of local and western cultures in EFL textbooks is then called the intercultural language learning model (Haerazi \& Irawan, 2020a). Intercultural language learning is echoed because globalization has made intercultural encounters more recurrent than ever (Raigón-Rodríguez, 2018). It is aligned with Arcagok and Yilmaz (2020), who state the English learners need to acquire target knowledge of language communities to reflect later their own cultures and beliefs in the form of intercultural communication.

The research is underpinned by the national educational system in terms of educational characters. The Indonesian curriculum (K13) encourages English teachers to acquire cultural knowledge and awareness as national characters. It aims to prepare students for becoming citizens who are religious, innovative, productive, and passionate (Kusumaningputri \& Widodo, 2018). It is in keeping with Young (2019), who argues that the English teachers should be able to integrate the harmony between local and global cultures in the EFL setting. In the context of middle schools (SMP/MTs), the teaching of English refers to the national curriculum (K13), where they are demanded to employ the local content curriculum in their teaching practice. The local content curriculum is oriented to attain national education qualities to equip students as an individual who has hard and soft skills (English proficiencies and values). In reaching this goal, English teaching materials (textbooks) can be designed and developed to bring students who have English skills and values (Safitri \& Tyas, 2019; Maryani \& Aguskin, 2019). Given that guided teaching-materials can facilitate students to learn and internalize their competencies and their own cultures.

The research aims to analyze target needs (what students need to learn) in developing culture-based instructional materials to enhance their critical thinking skills, ELT achievement, and classroom interaction. Based on this objective, the research questions proposed include; (1) what are the students' necessities of culture-based instructional material? (2) What are the students' lacks of culture-based instructional material? (3) Furthermore, what are the students' wants for culture-based instructional material? The results of the need analysis are used as a consideration of developing culture-based instructional materials.

\section{METHODS}

The current research belongs to a survey study that uses quantitative data. A survey is done to describe, compare, classify, evaluate, and interpret the research data (Cohen, Manion, \& Morrison, 2018). The research addresses students' and teachers' needs in EFL teaching at middle schools. The survey activities are directed to know some cultural aspects 
and intercultural dimensions incorporated in their teaching materials.

Given the various data, the research plans research steps or procedures to get the proper data. Some steps are initially conducted, such as the literature review to determine the validity and reliability of the used questionnaires. The blueprint of the questionnaire is developed in keeping with the literary study. After the questionnaire is classified as a valid and reliable one, researchers move to collect the data. The questionnaire is distributed to research subjects in some middle school students and teachers at Central Lombok. The 350 students and 10 English teachers have participated in the research. Researchers emphasize the data collection on students' target needs and learning needs. The attained data are coded, evaluated, analyzed, and interpreted in an in-depth narration.

This survey employs a questionnaire to attain the data. The questionnaire is categorized as a valid and reliable instrument that is validated and developed by experts. After it is declared as a valid one, researchers distribute it to research respondents. The respondents are asked to fill in 28 question items. The question aspects comprise necessities, lacks, wants, learning goals, inputs, procedures, teachers' roles, students' roles, and settings. Each item consists of 4-6 sub-questions. The researchers' team escorts them to control the respondents' feedback while filling the questionnaire in the class. It aims to lead them if they have difficulties in giving their answers to the questionnaire. For English teacher respondents, researchers provide them with a space column to write their opinions and experiences of incorporating cultures in their teaching materials. In doing so, the researchers' team accompanies them during the activities of filling the questionnaire. It makes it easier to give responses to questions and comments on some items.

The data attained from the questionnaire are analyzed quantitatively in the form of a percentage schema. To find this, the percentage formula is employed. Thus, the researchers classify the percentage of each research issue and coded the data. The coded data are evaluated by making the rubric and numeric data to guide readers easy to understand. The data then is interpreted in the form of narration. The researchers gather the data at one point in time to explain and depict the existing condition. The respondents' responses and feedback indicate their real condition in developing ELT materials to enhance students' critical thinking skills, academic achievement, and classroom interaction. At the same time, the researchers make a comparison between the data and the existed theories in line with the previous studies and research findings.

\section{RESULTS AND DISCUSSIONS}

The research findings indicate that most students and English teachers incorporate cultural aspects, both local cultures, and inner circle cultures, in their teaching materials. It is also not different from countries in expanded circles in which English is taught as a foreign language. Nevertheless, the middle schools' cultural materials at West Nusa Tenggara are designed and developed to attain intercultural competencies. In doing so, the target needs and learning needs are investigated and analyzed in the current research in terms of incorporating culture-based English teaching materials to improve students' critical thinking skills, English achievement, and classroom interaction. The data of learning needs are presented in Table 1.

The data of learning needs are collected

Table 1 The Target Needs of Culture-Based English Teaching for Students

\begin{tabular}{|c|c|c|c|c|c|c|}
\hline \multirow{2}{*}{$\begin{array}{c}\text { Components of } \\
\text { Target Needs }\end{array}$} & \multirow{2}{*}{ Assessed Aspects } & \multirow[t]{2}{*}{ Rank } & \multicolumn{4}{|c|}{ Percentage } \\
\hline & & & $\begin{array}{l}\text { Strongly } \\
\text { Agree }\end{array}$ & Agree & Disagree & $\begin{array}{l}\text { Strongly } \\
\text { Disagree }\end{array}$ \\
\hline \multirow[t]{9}{*}{ Necessities } & \multicolumn{6}{|c|}{ Students' needs of topic texts to learn in ELT classroom } \\
\hline & Giving familiar cultural topic texts & 1 & $85,7 \%$ & $7,1 \%$ & $7,1 \%$ & 0 \\
\hline & $\begin{array}{l}\text { Providing with topic texts indicating } \\
\text { daily activities }\end{array}$ & 2 & $78,8 \%$ & $8,5 \%$ & $9,7 \%$ & $2,8 \%$ \\
\hline & Giving texts relating to hobbies & 3 & $78,5 \%$ & $11,4 \%$ & $8,5 \%$ & $2,8 \%$ \\
\hline & $\begin{array}{l}\text { Providing with texts associating with } \\
\text { a social life. }\end{array}$ & 4 & $77,1 \%$ & $11,4 \%$ & $8,5 \%$ & $4,2 \%$ \\
\hline & $\begin{array}{l}\text { Giving topic texts relating to } \\
\text { religiosity }\end{array}$ & 5 & $76 \%$ & $12,5 \%$ & $5,7 \%$ & $5,7 \%$ \\
\hline & \multicolumn{6}{|c|}{ Students' needs about local cultural topics to learn in ELT classroom } \\
\hline & Cultural topics relating to local arts & 1 & $97 \%$ & $1,4 \%$ & $0,5 \%$ & $0,8 \%$ \\
\hline & $\begin{array}{l}\text { Cultural topics associating with local } \\
\text { games }\end{array}$ & 2 & $92,8 \%$ & $4,2 \%$ & $1,4 \%$ & $1,4 \%$ \\
\hline
\end{tabular}


Table 1 The Target Needs of Culture-Based English Teaching for Students (Continued)

\begin{tabular}{|c|c|c|c|c|c|c|}
\hline \multirow{2}{*}{$\begin{array}{l}\text { Components of } \\
\text { Target Needs } \\
\end{array}$} & \multirow[t]{2}{*}{ Assessed Aspects } & \multirow[t]{2}{*}{ Rank } & \multicolumn{4}{|c|}{ Percentage } \\
\hline & & & $\begin{array}{l}\text { Strongly } \\
\text { Agree }\end{array}$ & Agree & Disagree & $\begin{array}{l}\text { Strongly } \\
\text { Disagree }\end{array}$ \\
\hline & $\begin{array}{l}\text { Cultural topics relating to local ritual } \\
\text { performances }\end{array}$ & 3 & $91,4 \%$ & $4,2 \%$ & $2,8 \%$ & $1,4 \%$ \\
\hline & $\begin{array}{l}\text { Cultural topics associating with local } \\
\text { traditional technologies }\end{array}$ & 4 & $90 \%$ & $4,2 \%$ & $2,8 \%$ & $2,8 \%$ \\
\hline & $\begin{array}{l}\text { Cultural topics relating to local } \\
\text { literatures }\end{array}$ & 5 & $85 \%$ & $4,8 \%$ & $4,2 \%$ & $5,1 \%$ \\
\hline \multirow[t]{10}{*}{ Lacks } & \multicolumn{6}{|c|}{ Students' needs to improve through cultural topics } \\
\hline & Speaking skills & 1 & $99 \%$ & $0,5 \%$ & $0,2 \%$ & 0 \\
\hline & Reading skills & 2 & $97 \%$ & $1,4 \%$ & $0,8 \%$ & $0,5 \%$ \\
\hline & Listening skills & 3 & $90 \%$ & $4,2 \%$ & $2,8 \%$ & $1,4 \%$ \\
\hline & Writing skills & 4 & $82,8 \%$ & $8,5 \%$ & $4,2 \%$ & $4,2 \%$ \\
\hline & \multicolumn{6}{|c|}{ Students' current real ability of English achievement } \\
\hline & Speaking skills & 1 & $82,8 \%$ & $8,5 \%$ & $8,5 \%$ & 0 \\
\hline & Listening skills & 2 & $80 \%$ & $10 \%$ & $8,5 \%$ & $1,4 \%$ \\
\hline & Reading skills & 3 & $78,5 \%$ & $10 \%$ & $8,5 \%$ & $2,8 \%$ \\
\hline & Writing skills & 4 & $71,4 \%$ & $11,4 \%$ & $11,4 \%$ & $5,7 \%$ \\
\hline \multirow[t]{6}{*}{ Wants } & \multicolumn{6}{|c|}{ Students' needs to learn and improve in ELT classroom } \\
\hline & Vocabulary mastery & 1 & $99 \%$ & 0 & $0,5 \%$ & $0,2 \%$ \\
\hline & Grammatical competence & 2 & $98,5 \%$ & $0,5 \%$ & $0,5 \%$ & $0,2 \%$ \\
\hline & Communicative fluency & 3 & $98 \%$ & $0,8 \%$ & $0,5 \%$ & $0,5 \%$ \\
\hline & Comprehending English texts & 4 & $95,1 \%$ & $1,4 \%$ & $1,4 \%$ & $2 \%$ \\
\hline & Comprehending native speakers & 5 & $94,8 \%$ & $1,7 \%$ & $1,4 \%$ & $2 \%$ \\
\hline
\end{tabular}

using a questionnaire. The items are addressed on students' necessities, lacks, and wants. According to Rachmawati (2020) and Raigon-Rodriguez (2018), English teachers need to conduct a need analysis on learning necessities, students' lacks, and students' wants before designing the teaching materials. It aims at preparing students' appropriate materials in order to achieve learning goals in EFL classes. The current research addresses the students' lack in order to know their current English language skills before providing them with culture-based instruction. Besides, the students' desirability to learn in joining to culturebased instruction needs to be revealed.

Based on the necessary analysis, most students refer to the texts containing familiar topics. The teachers feel helpful to organize the classes if the students do the learning activities through texts that students understand. It is in line with Cinganotto (2019), who conducts online EFL learning to activate students' learning interaction. The learning process is easy to manage as the learning materials guided students to carry out activities and exercises. The same tone is found by Haerazi et al. (2020), who inform that the familiar topics for students encourage them to accomplish their assignments efficiently.

As intercultural communication is increasing global interconnectedness, it happens more frequently, including high schools and higher education. Given the importance of this issue, students have desirability and tendencies to learn their own cultures containing values before moving to the target cultures. It accords with Nielsen et al. (2019), who report that English learners in intercultural instruction are making an intimate connection between cultural sensitivity, social structures, and social-emotional competencies. In this current research, students indicate that they have the desirability to master English language skills through culture-based instruction. In terms of English as an international language, students do not need to depend on the British and American cultural schema of native speakers to convey meaning and interact with other English users (Shin, Eslami, \& Chen, 2011). In this circumstance, English teachers just need to provide for students teaching materials that combine their local cultures and the target cultures.

Table 1 shows the students' second choices to learn in culture-based EFL learning, including texts indicating daily activities. The texts relating to 
hobbies are in the third option of students, and the texts containing religiosity are the last option. Based on the data analysis, most students do not perform texts containing information about daily activities, hobbies, and religiosities because these texts are not to encourage them to get scientific knowledge. Further, the religiosity texts are uneasy to understand and are needed more knowledge to comprehend. That is why it is the last option for students to learn in EFL classes. Dealing with cultural topics, mostly, students chose the local cultural topics to facilitate them to learn English skills, critical thinking skills, and classroom interaction. The same results are shown by Colaiacomo and Puntil (2018). They state students can learn English skills through ELT materials incorporating local cultural topics in textbooks. It is also for improving critical thinking (Kusumoto, 2018).

Dealing with students' lacks, the researchers address two points. The first one is about the students' language skills to improve, and the second issue relates to the students' current English ability. Most students tend to improve speaking skills rather than the three skills (listening, reading, and writing) for the first issue. It is because students argue that speaking is an important skill to be acquired. Speaking is also more promising because they are staying in tourism areas. Because of this, speaking is more useful for them. Compared to speaking, writing is assumed as the most difficult. It is in accordance with some studies that show students feel uneasy about acquiring writing skills because it requires many aspects such as linguistics competences, meta-cognition regulation, and socio-cultural competences (Haerazi \& Irawan, 2020b; Tafazoli, Parra, \& Abril, 2018; García \& da Silva, 2018; and Sato \& Loewen, 2018). The data of students' lacks also indicate that students need to improve their speaking skills.

The data illustrate that students feel curiosity and snooping over speaking competence because they stay in Lombok, West Nusa Tenggara, where many foreigners come to this place for a holiday for a few days or weeks. As a tourism area, it is a big opportunity for students to learn English. Also, they feel they have an excellent chance to explore their speaking ability to communicate with English native speakers or English users. From 320 students of junior high schools at central Lombok, most students have high expectations of speaking skills in the culturebased instruction. The data are also supported by 10 teachers who are asked to fill the questionnaire. The teachers argue that the highest demand for students after they learn English in their school is to master speaking skills. It possibly influences them to acquire speaking skills, although some also need to acquire other language skills. This finding was in line with Hsu (2019), who develop learning tasks repetition and post-task transcribing to acquire speaking skills because speaking skills are considered a vital issue in international communication.

Besides, the current research indicates that students in middle schools imply that they want to develop the four language skills, respectively. The language dimensions that they need to improve include vocabulary acquisition, grammatical competence, and communicative fluency. Table 1 shows that vocabulary mastery is the main dimension that students necessitate to acquire. Students realize that vocabulary is essential to communicate. Some studies show that it can help students to send information and understand a message delivered by English speakers with having good vocabulary mastery (Ajabshir \& Sadeghi, 2019; Mustafa et al., 2019; \& Indrasari, Novita, \& Megawati, 2018). In the model of culture-based language learning, students need to improve their vocabulary acquisition. After the vocabulary, students tend to have grammatical knowledge. The data indicate that students should have good grammatical competence to read and write English texts. It is in line with Biber and Gray in Crosthwaite (2018), who state that the better students have grammatical competence, the better students have reading comprehension and writing skills.

Compared to vocabulary and grammatical knowledge, communicative fluency is not the main purpose for students who are willing to be involved in culture-based language learning. English fluency for students can be acquired after they attain the vocabulary and grammatical knowledge. The data inform that students' problems are the students who have low speaking and reading skills because they do not have a good vocabulary and grammatical knowledge. Moreover, students do not fully pay an intended English fluency, specifically in communicative fluency. Part 'want' in Table 1 confirms that communicative fluency is uneasy to achieve because they do not have adequate linguistic knowledge such as grammar and vocabulary. It is reinforced by some studies that indicate the communicative fluency can be acquired by students since they are given much more a chance to use the target language inside and outside the class (Agudo, 2020; Vold, 2020; Hsu, 2019; Haerazi \& Irawan, 2020b). In developing the culture-based language learning materials, students are directed to strengthen their communicative competence. In doing so, the teaching materials are designed in line with the curriculum goals for the middle school students. The skills of comprehending texts and understanding native speakers' utterances are considered in the research.

\section{CONCLUSIONS}

The research focuses on analyzing students' learning needs and the target needs of developing the culture-based English instructional materials to enhance students' critical thinking skills, ELT achievement, and classroom interaction at the middle schools. Based on the analysis results, students' learning needs refer to learning goals, inputs, learning activities, teachers' roles, students' roles, and classroom management. The learning goals are designed in line with the existing school curriculum. 
The students' inputs are developed to guide students to improve their language skills, critical thinking skills, EFL achievement, and classroom interaction to achieve their goals. In doing so, the culture-based materials are designed in the form of appropriate learning activities in accordance with the students' English proficiency. The roles of teachers and students are essential in this circumstance. Besides, classroom management is arranged in line with the learning activities that lead students to attain the learning goals.

Dealing with the target needs, the data confirm that the target needs comprise the instructional goals, lacks, and wants. In terms of instructional goals, students expect that the culture-based language instructional model can increase their ELT achievement and pass their school's passing grade. Their current English ability is still beneath standard. Because of this, they necessitate various cultures as their teaching materials in ELT classes. Mostly, students intend to learn speaking, reading, listening, and writing skills, respectively. To attain the speaking skills, they are enthusiastic about learning linguistic elements such as vocabulary, grammar, fluency, accuracy, and pronunciation in the culture-based language learning contexts. The cultural topics that are mostly chosen include local cultures such as local arts, traditional games, traditional rates, traditional technologies, and traditional pieces of literature.

The research limitation lies in the aspects of analyzing students' target needs, which are issues of the necessary, lacks, and wants. It does not continue practicing the result of need analysis in the form of textbooks. Drawing the limitation of the research in terms of continuous instruction, future instructors or researchers should analyze the issues in relation to students' and teachers' technological knowledge, pedagogical knowledge, and content knowledge in developing culture-based instructional materials.

\section{ACKNOWLEDGMENT}

The research was financially supported by the Directorate for higher education, the Ministry of Education and Culture of Indonesia Republic, under postgraduate fund program (HIBAH TESIS) 2020.

\section{REFERENCES}

Agudo, J. D. M. (2020). The impact of CLIL on English language competence in a monolingual context: A longitudinal perspective. Language Learning Journal, 48(1), 36-47. https://doi.org/10.1080/0957 1736.2019.1610030.

Ajabshir, Z. F., \& Sadeghi, K. (2019). The impact of asynchronous computer-mediated instruction (CAI) on EFL learners' vocabulary uptake across different proficiency levels. Teaching English with Technology, 19(3), 68-89.

Alaei, M. M., \& Parsazadeh, H. (2020). Culture in English language teaching textbooks: The emergence of a synergistic blueprint. Asian Englishes, 22(1), 101105. https://doi.org/10.1080/13488678.2019.16671 71.

Arcagok, S., \& Y1lmaz, C. (2020). Intercultural sensitivities: A mixed methods study with pre-service EFL teachers in Turkey. Issues in Educational Research, 30(1), 1-18.

Baker, W. (2017). Culture and identity through English as a lingua franca: Rethinking concepts and goals in intercultural communication. ELT Journal, 71(3), 390-392. https://doi.org/10.1093/elt/ccx022.

Cinganotto, L. (2019). Online interaction in teaching and learning a foreign language: An Italian pilot project on the companion volume to the CEFR. Journal of E-Learning and Knowledge Society, 15(1), 135-151. https://doi.org/10.20368/1971-8829/1618.

Cohen, L., Manion, L., \& Morrison, K. (2018). Research methods in education ( $\left.8^{\text {th }} \mathrm{Ed}\right)$. New York: Routledge.

Colaiacomo, S., \& Puntil, D. (2018). Intercultural learning - An undergraduate module supporting the development of students' cultural awareness in international settings. Language Learning in Higher Education, 8(1), 187-196. https://doi.org/10.1515/ cercles-2018-0011.

Crosthwaite, P. (2018). Grammatical complexity in academic English Douglas Biber Bethany Gray 2016. World Englishes and Second language Acquisition, 37(1), 140-141. https://doi.org/10.1111/weng.12309.

Dinh, T. N., \& Sharifian, F. (2017). Vietnamese cultural conceptualisations in the locally developed english textbook: A case study of 'lunar new year'/'tet.' Asian Englishes, 19(2), 148-159. https://doi.org/10. 1080/13488678.2017.1279763.

Forman, R. (2014). How local teachers respond to the culture and language of a global English as a Foreign Language textbook. Language, Culture, and Curriculum, 27(1), 72-88. https://doi.org/10.1080/07 908318.2013.868473.

García, M. R., \& da Silva, P. F. (2018). Acquisition of language and intercultural competences in tourism and hospitality studies through active experimentation in Second Life. Teaching English with Technology, 18(2), 69-92.

Haerazi., Irwansyah, D., Juanda., \& Azis, Y. A. (2018). Incorporating intercultural competences in developing English materials for writing classes. Journal of Language Teaching and Research, 9(3), 540-547. https://doi.org/10.17507/jltr.0903.13.

Haerazi., Vikasari, R. M., \& Prayati, Z. (2019). The use of scientific-based approach in ELT class to improve students' achievement and classroom interaction. Register Journal, 12(2), 157-180. https://doi. org/10.18326/rgt.v12i2.157-180.

Haerazi., Irawan, L. A., Suadiyatno, T., \& Hidayatullah, H. (2020). Triggering preservice teachers' writing skills through genre-based instructional model viewed from creativity. International Journal of Evaluation and Research in Education, 9(1), 234-244. https:// doi.org/10.11591/ijere.v9i1.203945.

Haerazi, H. \& Irawan, L. A. (2020a). Developing Intercultural Language Learning (ILL) model 
to teach writing skills at Indonesian private universities. EduLite: Journal of English Education, Literature and Culture, 5(1), 43-54. https://doi. org/10.30659/e.5.1.43-54.

Haerazi, H., \& Irawan, L. A. (2020b). The effectiveness of ECOLA technique to improve reading comprehension in relation to motivation and self-efficacy. International Journal of Emerging Technologies in Learning, 15(1), 61-76. https://doi. org/10.3991/ijet.v15i01.11495.

Hsu, H. C. (2019). The combined effect of task repetition and post-task transcribing on L2 speaking complexity, accuracy, and fluency. Language Learning Journal, 47(2), 172-187. https://doi.org/10.1080/09571736.2 016.1255773 .

Imig, A. (2016). The cultural and intercultural dimensions of English as a lingua franca. Asian Englishes, 8678, 1-221. https://doi.org/10.1093/elt/ccx040.

Indrasari, A., Novita, D., \& Megawati, F. (2018). Big book: Attractive media for teaching vocabulary to lower class of young learners. JEES (Journal of English Educators Society), 3(2), 141-154. https://doi. org/10.21070/jees.v3i2.1572.

Joo, S. J., Chik, A., \& Djonov, E. (2020). The construal of English as a global language in Korean EFL textbooks for primary school children. Asian Englishes, 22(1), 68-84. https://doi.org/10.1080/13488678.2019.1627 636.

Kubota, R. (2018). Unpacking research and practice in world Englishes and second language acquisition. World Englishes, 37(1), 93-105. https://doi.org/10.1111/ weng. 12305 .

Kusumaningputri, R., \& Widodo, H. P. (2018). Promoting Indonesian university students' critical intercultural awareness in tertiary EAL classrooms: The use of digital photograph-mediated intercultural tasks. System, 72, 49-61. https://doi.org/10.1016/j. system.2017.10.003.

Kusumoto, Y. (2018). Enhancing critical thinking through active learning. Language Learning in Higher Education, 8(1), 45-63. https://doi.org/10.1515/ cercles-2018-0003.

Maryani, M., \& Aguskin, L. (2019). Incorporating Youtube clips in the classroom to develop students' cultural understanding of American culture. Lingua Cultura, 13(4), 265-273. https://doi.org/10.21512/ lc.v13i4.5889.

Mustafa, F., Assiry, S. N., Bustari, A., \& Nuryasmin, R. A. (2019). The role of vocabulary e-learning: Comparing the effect of reading skill training with and without vocabulary homework. Teaching English with Technology, 19(2), 21-43.

Nielsen, B. L., Laursen, H. D., Reol, L. A., Jensen, H., Kozina, A., Vidmar, M., Rasmusson, M., Marušić, I., Denk, A., Roczen, N., Jurko, S., \& Ojstersek, A. (2019). Social, emotional, and intercultural competencies: A literature review with a particular focus on the school staff. European Journal of Teacher Education, 42(3), 410-428. https://doi.org/ 10.1080/02619768.2019.1604670.

Niman, E. M., Budijanto., Astina, I. K., Susilo, S., \&
Darong, H. C. (2020). Local culture in social studies textbooks: Is it contextualised? International Journal of Innovation, Creativity and Change, 11(8), 293-310.

Rachmawati, U. (2020). What lies behind the students' need in English for specific purposes: A reflection of needs analysis. JOLLT Journal of Languages and Language Teaching, 8(2), 213-221. https://doi. org/10.33394/jollt.v\%vi\%i.2537.

Raigón-Rodríguez, A. (2018). Analysing cultural aspects in EFL textbooks: A skill-based analysis. Journal of English Studies, 16, 281-300. https://doi. org/10.18172/jes.3478.

Safitri, R., \& Sugirin, S. (2019). Senior high school students' attitudes towards intercultural insertion into the ELT: Yogyakarta context. EduLite: Journal of English Education, Literature, and Culture, 4(2), 261-274. https://doi.org/10.30659/e.4.2.261-274.

Safitri, M., \& Tyas, P. A. (2019). An analysis of English textbook entitled "Bahasa Inggris SMA/MA SMK/ MAK Kelas X”. JEES (Journal of English Educators Society), 4(1), 17-22. https://doi.org/10.21070/jees. v4i1.1777.

Sato, M., \& Loewen, S. (2018). Metacognitive instruction enhances the effectiveness of corrective feedback: Variable effects of feedback types and linguistic targets. Language Learning, 68(2), 507-545. https:// doi.org/10.1111/lang.12283.

Setyono, B., \& Widodo, H. P. (2019). The representation of multicultural values in the Indonesian Ministry of Education and Culture-endorsed EFL textbook: A critical discourse analysis. Intercultural Education, 30(4), 383-397. https://doi.org/10.1080/14675986.2 019.1548102.

Shin, J., Eslami, Z. R., \& Chen, W. C. (2011). Presentation of local and international culture in current international English-language teaching textbooks. Language, Culture and Curriculum, 24(3), 253-268. https://doi. org/10.1080/07908318.2011.614694.

Sridhar, S. N. (2019). Professor Braj B. Kachru (1932-2016): A cultural warrior rests his case. World Englishes, 38(1-2), 5-7. https://doi.org/10.1111/weng.12416.

$\mathrm{Su}, \mathrm{Y}$. (2016). The international status of English for intercultural understanding in Taiwan's high school EFL textbooks. Asia Pacific Journal of Education, 8791(March), 1-19. https://doi.org/10.1080/0218879 1.2014.959469.

Tafazoli, D., Parra, M. E. G., \& Abril, C. A. H. (2018). A cross-cultural study on the attitudes of English language students towards computer-assisted language learning. Teaching English with Technology, 18(2), 34-68.

Tamimy, M. (2019). The cultural attitudes towards cooperative learning: What proverbs can offer. Journal of Intercultural Communication Research, 48(4), 416-434. https://doi.org/10.1080/17475759.2 019.1639536.

Vold, E. T. (2020). Meaningful and contextualised grammar instruction: What can foreign language textbooks offer? Language Learning Journal, 48(2), 133-147. https://doi.org/10.1080/09571736.2017.1357745. 
Young, M. S. (2019). Indonesia's Local Content Curriculum (LCC) initiative: Decentralization and perspectives from high school classrooms in Banten. Indonesian Research Journal in Education IRJE, 3(1), 141-167. https://doi.org/10.22437/irje.v3i1.6671. 